\title{
MASALAH SAMPAH PLASTIK IMPOR DAN DAMPAKNYA TERHADAP LINGKGUNGAN HIDUP
}

\author{
Salman Luthan
}

\section{A. Pendahuluan}

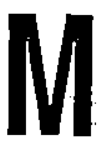

enjelang pembukaan Konvensi Basel II yang umembicarakan masalah ekspor sampah B3 beberapa.:-waktu yang lalu, kelompok Greenpeace menggelar aksi protes terhadap negara-negara industri yang menentang pelarangan total ekspor sampah bahan berbahaya dan beracun (B3) ke Dunia Ketiga. Aksi yang melibatkan tidak kurang 60 orang anggota kelompok pecinta lingkungan tersebut dilakukan dengan cara membuang satu ton sampah impor di depan markas besar PBB di Jenewa.

Sampah yang dibuang tersebut adalah sampah plastik impor Indonesia yang berasal dari negara-negara industri, seperti Belanda, Jerman, Amerika Serikat; Jepang, Singapura, dan Hongkong. Barang-barang rongsokan yang mengandung $\mathrm{B} 3$ dan tidak dapat didaur ulang tersebut diangkut oleh kapal MV. Greenpeace daripelabuhan Tanjung Priok ke Jenewa. Pengapalan sampah impor tersebut berdasarkan kesepakatan antara aktivis Greenpeace dengan para pemulung se Jabotabek dan Wahana Lingkungan Hidup Indonesia (Walhi).

Dalam aksi protes tersebut dipajang poster yang berbunyi Asla is not your waste dump di atas bendera negaranegara industri. Inilah salah satu bentuk reaksi sosial terhadap transaksi perdagangan sampah plastik impor.

Cuplikan peristiwa tersebut menggambarkan bahwa masalah sampah impor telah menjadi isu internasional yang melibatkan pemerintah negara-negara industri dan pemerintah negara-negara berkembang serta organisasi-organisasi nonpemerintah (Nongovernmental Group Organization atau NGO) di kedua kawasan tersebut:

Besarnya perhatian terhadap masalah : sampah plastik impor menunjukkan tingginya kepedulian masyarakat internasional terhadap lingkungan hidup, yang bukan hanya merupakan tempat hidup manusia, tapi juga tempat, berdiam makhluk hidup lainnya.

Masalah sampah impor disinyalir sudah ada di Indonesia sejak tahun 1989 , namun pada waktu itu belum begitu digubris oleh pihak berwajib., Indikasi terjadinya manipulasi pemasukan sampah plastik impor yang mengandung limbah B3 berawal dari informasi para pemulung (scavengers atau plastic garbage collector), yang menemukannya di. tempattempat pembuangan sampah.

Kasus sampah plastik impor ini pada tingkat mikro (nasional) mencuatkan adanya perbedaan kepentingan antara kepentingan bisnis dengan kepentingan ketenagakerjaan atau antara kepentingan orang kaya (pengusaha dan industriawan) dengan kepentingan orang miskin (para pemulung). Para pengusaha dan industriawan lebih suka membeli sampah impor daripada sampah hasil pengumpulan para pemulung sebab harga sampah impor jauh lebih murah. 
Jika impor sampah plastik tidak dihentikan, maka para pemulung akan kehilangan pangsa pasar untuk menjual barang-barang plastik bekas yang mereka kumpulkan. Dengàn kata lain; para pemulung akan kehilangan mata pencaharian (penghasilan) untuk sekedar biaya penyambung hidup keluarganya.

Pertentangan kepentingan bisnis dengan kepentingan pengelolan lingkungan terdapat pada penumpukan sampah plastik di dalam negeri, karena sampah-sampah lokal tidak bisa dijual dan tidak bisa didaur ulang. Hal ini tentu mempunyai implikasi lebih buruk terhadap lingkungan hidup, baik untuk penyediaan lahan bagi pembuangan sampah-maupun terhadap kesehatan manusia.

Pada level makro (global) masalah sampah plastik impor menggambarkan adanya pertentangan kepentingan antara negara-negara industri (sebagai pengekspor) dengan negara-negara berkembang (sebagai pengimpor). Negara-negara industri cenderung tidak mau mengolah sendiri sampah-sampah plastik dan limbah-limbah industri yang dihasilkannya, karena biaya pengolahannya cukup mahal, apalagi jika sampah itu mengandung B3. Cara yang paling mudah untuk memecahikan masalah sampah tersebut adalah mengekspornya ke negara-negara Dunia Ketiga. Dengan cara seperti itu mereka dapat mengatasi pencemaran dan kerusakan lingkungan yang terjadi di negaranya, meski hal itu jelas mendatangkan masalah baru bagi Dunia Ketiga yang secara teknologis. kurang mempunyai kemampuan untuk mendaur ulang barang-barang tersebut.

Hal ini menunjukkan bahwa negaranegara industri yang selama ini selalu mendengung-dengungkan isu lingkungan hidup dalam pemberian utang luar negeri kepada negara-negara Dunia Ketiga, ternyata tidak punya komitmen yang sejati dalam bidang lingkungan, sekaligus menunjukkan bahwa kepentingan nasionalnya lebih utama daripada kepentingan universal menyelamatkan lingkungan alam semesta ini.

Dalam menghadapi masalah ini pemerintah Indonesia" sebenarnya bersikap sangat responsif dalam mencari penyelesaian dengan mengeluarkan larangan impor sampah plastik seperti tertuang dalam Surat Keputusan Menteri Perdagangan No. 349/KP/X1/1992 tertanggal 21 Nopember 1992, meski kenyataannya kegiatan impor sampah plastik masih terus berlanjut hingga akhir tahun 1993*. Pihak Bea dan Cukai menuduh. PT. Surveyor Indonesia dan SGS sebagai pihak yang harus bertanggungjawab terhadap masuknya sampah impor itu, karena adanya fakta bahwa barang-barang tersebut dilengkapi dengan laporan pemeriksaan surveyor.

\section{B. Deskripsl Kasus Sampah Plastik Impor}

Kasus sampah plastik berawal dari transaksi perdagangan antar negara (ekspor impor) yang melibatkan negaranegara industri seperti Belanda, Jepang, Amerika, Jerman, Hongkong dan Singapura sebagai pengekspor dan Indonesia sebagai negara pengimpor. Transaksi perdagangan tersebut adalah antara pengusaha Indonesia dengan penguasaha negàra-negara industri tersebut.

Sebelum adanya SK Menteri Perdagangan No. 349/Kp/Xl/1992 tidak ada larangan impor sampah plastik. Artinya ia baru menjadi tindakan illegal, setelah tanggal pemberlakuan SK tersebut, yaitu 21 Nopember 1992.

\footnotetext{
- Hasil temuan berbagai instansi dan LSM tentang jumlah sampah impor ini beragam. Menurut Humas Kejaksaan Agung terdapat 247 petikemas sebesar $4.818,5$ ton. Bapedal menyebut 500 kontainer, sementara Walhi mencatat 254 petikemas. Sebagian besar sampah plastik impor tersebut menumpuk di pelabuhan Tanjung Priuk Belawan dan Tanjung Perak Surabaya.
} 
Kasus sampah plastik impor ini bukan hanya menyangkut sampah plastik yang dimpor setelah berlakunya SK menteri Perdagangan tersebut, tapi juga bertubungan dengan sampah plastik yang diimpor sebelum SK tersebut. Untuk mengetahui lebih jauh tentang kuantitas dan sifat sampah impor tersebut, negaranegara pengekspor, dan perusahaan pengimpornya dapat dijelaskan dengan tabel-tabel berikut ini.

\section{Kuantitas Sampah Plastik Impor}

\begin{tabular}{lc}
\hline No: Sifat Daur Ulang & $\begin{array}{c}\text { Jumlah } \\
\text { Kontainer }\end{array}$ \\
\hline 1. : Dapat didaur ulang & 136 kontaiñer \\
2. : Tidak dapat didaur ulang & 104 kontainer \\
3. : Belum diadakan pengujian & 21 kontainer \\
\hline
\end{tabular}

261 kontainer

Sumber: Bapedal

Jumlah sampah plastik impor sebanyak 261 kontainer tersebut merupakan hasil impor sejak tahun 1989 sampai dengan tahun 1994, namun Bapedal tidak memiliki data distribusi kasus per tahun. Jumlah sampah plastik impor yang tidak mengandung B3 adalah 136 kontainer, termasuk dalam kategori positive list, artinya dapat didaur ulang dengan menggunakan teknologi tertentu. Sedangkan yang me- ngandung B3 termasuk kategori negative list, yaitu sampah yang tidak dapat didaur ulang. Ada 21 kontainer sampah plastik impor tersebut yang belum diadakan pengujian laboratorium, sehingga belum diketahui jenisnya, apakah dapat didaur ulang atau tidak.

Negara-negara yang mengekspor sampah plastik mengandung limbah B3 adalah sebagai berikut:
Limbah Plastlk Impor Mengandung B3 Yang tidak Dapat Didaur Ulang (Masuk Negatif List)

\begin{tabular}{llr}
\hline No Nega ra & Jumlah Kontainer \\
\hline 1. Belanda & $=75$ kontainer \\
2. Jerman & $=5$ kontainer \\
3. Jepang & $=1$ kontainer \\
4. Singapura & $=13$ kontainer \\
5. Amerika & $=8$ kontainer \\
6. Hongkong & $=1$ kontainer \\
7. Tdk diketahui negaranya & $=1$ kontainer \\
\hline & \multicolumn{1}{c}{$:$} & \\
\hline
\end{tabular}

Sumber: Bapedal

Tábel tersebut di atas terihat bahwa Belanda merupakan negara yang paling banyak mengeks-por sampah plastik yang mengandung bahan berbahaya dan beracun ke Indonesia, kemudian diikuti Singapura dan Jerman. Limbah- limbah tersebut sesuai dengan Konvensi Basel terdiri dari kontaminan-kontaminan dengan berbagai kode limbah. Tabel berikut ini akan menjelaskan jenis-jenis kontaminan yang terdapat dalam sampah plastik impor tersebut.

Tabel 3

Kontaminan Limbah/Sampah Plastlk Impor Yang Mengandung B3

No. Kode Kontaminan Limbah Jumlah Kontainer

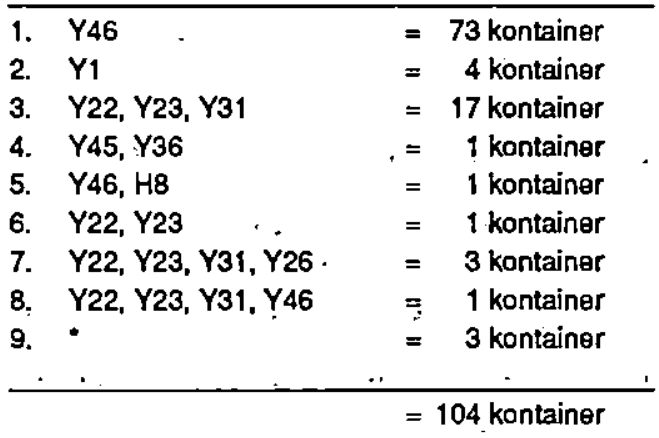

Sumber: Bapedal 
Keterangan

1. Y1 : Limbah klinis (botol infus)

2. Y22: Limbah dengan bahan pencemar utama Copper

3. Y23 : Limbah dengan bahan pencemar utama Zinc

4. Y31 : Limbah dengan bahan pencemar utama Lead.

5. Y26 : Limbah dengan bahan pencemar utama Cadmium

6. Y45 : Limbah dengan bahan pencemar pelarut organik

7. Y46: Limbah rumah tangga

8. H8: Limbah plastik kemasan bahan korosif

9. - : Limbah plastik kotor (berlumpur)

Sampah plastik impor yang mengandung limbah B3 itu yang paling banyak dari jenis limbah rumah tangga (Y46), baik limbah rumah tangga murni, maupun yang telah bercampur plastik bekas kemasan korosif dan yang telah bercampur dengan bahan pelarut organik. Kemudian limbah dengan bahan pencemar utama campuran antara Copper (Y22), Zinc (Y23) dan Cadmium (Y26), dan limbah klinis.

Sedangkan perusahaan pengimpor sampah plastik tersebut kebanyakan dari Jakarta, dan sebagian kecil dari Surabaya dan Medan. Perusahaan pengimpor sampah mengandung B3 setelah berlakunya SK Menteri Perdagangan tergambar dalam tabel.4.

\section{Tabel 4}

Perusahaan Pengimpor Sampah B3 (Setelah 25 Nopember 1992)

Perusahaan Alamat jenis Limbah $\begin{aligned} & \text { Jumlah } \\ & \text { Kontainer }\end{aligned}$

1.PT. ICM Jakarta

\section{Rumah tangga} Logam berat

2. PT. E.S.R.A Jakarta

Rumah tangga

Klinis

3. PT. S.G.M. Jakarta

4. PT. D.U. Jakarta

Rumah tangga sampah berlumpur

Logam berat

Klinis

5. PT. C.I.A. Jakarta

6. PT. M.I. Jakarta

7. PT. W.M. Jakarta

8. PT. N.S.N.B. Jakarta

Klinis

Klinis

Rumah tangga

Rumah tangga

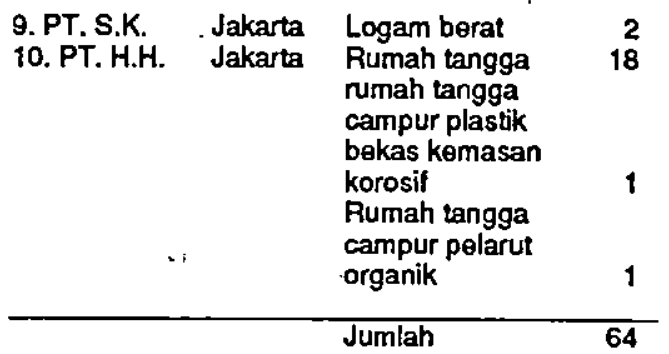

Sumber: Walhi

Menurut Walhi ada 64 kontainer sampah plastik impor yang dimasukkan melalui pelabuhan Indonesia setelah berlakunya SK Menteri Perdagangan No.349/Kp/X1/1992 yang melarang impor sampah plastik. Data dari Walhi ini berbeda dengan data dari Bapedal, karena menurut penelitian Bapedal hanya ada 21 kontainer sampah plastik impor setelah berlakunya SK Menteri Perdagangan tersebut.

\section{Dampak Sampah Plastik Impor}

Sampah plastik impor yang masuk ke Indonesia jelas mempunyai dampak terhadap kehidupan masyarakat, baik terhadap kehidupan ekonomi maupun terhadap lingkungan hidup. Namun demikian harus dibedakan antara dampak yang ditimbulkan oleh sampah plastik impor yang mengandung B3 dan sampah plastik impor yang tidak mengandung B3. Sampah plastik impor yang mengandung B3 mempunyai tingkat bahaya lebih tinggi daripada sampah plastik impor yang tidak mengandung B3. Sampah atau limbah yang mengandung B3 memiliki kharakteristik mudah meledak, mudah terbakar, bersifat reaktif, beracun, bersifat korosif, dan bisa menyebabkan infeksi.

Dampak sampah plastik impor terhadap kehidupan ekonomi masyarakat terutama berkaitan dengan kerugian finansial yang dialami oleh Indonesia, yaitu biaya pengolahan sampah plastik impor tersebut, harga sewa lokasi kontainer di pelabuhan dan kenugian yang dialami para pemulung. 
Jumlah sampah atau limbah plastik bekas yang diimpor adalah 3000 ton per bulan, dengan komposisi 60 persen dapat didaur ulang dan 40 persen tidak dapat didaur ulang. Sampah plastik impor yang mengandung B3 harus ditangani secara khusus, tidak boleh dibuang begitu saja ke TPA dan biaya pengolahannya mahal. Biaya yang harus dikeluarkan untuk pengolahan plastik biasa (non B-3) sebesar Rp. 337.500 .000 per bulan, untuk pengolahan plastik yang mengandung $B 3$ adalah Rp. 480.000 .000 per bulan, dan untuk pengolahan sampah plastik yang tidak dapat didaur ulang sebesar Rp. 817.500 .000 per bulan. Biaya tersebut belum termasuk biaya transportasi ke lokasi pembuang-an dan biaya penyewaan lahan tempat penumpukan kontainerkontainer yang tidak diakui pengimpornya di pelabuhan-pelabuhan.

Kerugian finasial lainnya adalah penurunan penghasilan pemulung kareria limbah plastik lokal yang dikumpulkan oleh mereka tidak terserap oleh industri pendaur ulang. Jumlah limbah plastik lokal hasil pengumpulan pemulung yang tidak terserap atau terjual mencapai 40 persen dari jumlah total yang dikumpulkan sebesar 3000 ton per bulan.

Harga penjualan juga turun sampai 50 persen sehingga penghasilan pemulung turun dari Rp. 6000 per hari menjadi $R p$. 3000 per hari. Penurunan penghasilan ini tentu mempengaruhi pemenuhan kebutuhan sehari-hari para pemulung beserta keluarganya. Penurunan penghasilan para pemulung hanya berlangsung sampai dengan dikeluarkannya SK Menteri Perdagangan No. $349 / \mathrm{Kp} / \mathrm{XI} / 1992$ yang melarang impor sampah plastik. Dengan adanya SK tersebut, sampah plastik yang dikumpulkan oleh para pemulung kembali terserap oleh industri pendaur ulang plastik.

Di samping mempunyaí dampak ekonomis, sampah plastik impor juga mempunyai dampak terhadap lingkungan hidup, khususnya terhadap pencemaran sampah dan gangguan kesehatan manusia. Sampah plastik impor yang tidak dapat didaur ulang akan dibuang ke tempat pembuangan akhir sampah (TPA), yang seharusnya digunakan untuk pembuangan sampah dalam negeri. Oleh karena itu terjadi penumpukan sampah yang banyak sekali.

Sementara itu sampah plastik impor yang mengandung B3 harus ditangani secara khusus, tidak boleh dibuang begitu saja ke TPA. Pembuangan sampah plastik impor yang mengandung B3 ke tempattempat pembuangan sampah mengakibatkan gangguan kesehatan terhadap pemulung.

Di samping itu, sampah impor yang termasuk kategori bisa didaur ulang, ternyata tidak semuanya dapat didaur ulang oleh pengimpornya. Plastik-plastik bekas itu kemudian dibuang ke tempattempat pembuangan sampah. Hasil produk pendauran ulang ternyata juga tidak memenuhi performan standar yang baik dan tidak memenuhi upaya pengelolaan lingkungan yang baik. Dengan kata lain, sampah impor yang bisa didaur ulang tersebut juga mencemari lingkungan hidup.

\section{Faktor-Faktor Penyebab}

Kàsus sampah plastik impor yang terjadi dalam masyarakat kita terutama disebabkan oleh kelemahan sistem peraturan perundang-undangan, khususnya peraturan tentang ekspor impor sampah dan limbah bahan berbahaya dan beracun. Sebagian besar sampah plastik impor yang masuk ke Indonesia datang sebelum Indonesia memiliki peraturan perundang-undangan yang melarang impor sampah dan adaya peraturan tentang limbah bahan berbahaya dan beracun. Dari 261 kontainer limbah atau sampah plastik impor yang masuk Indonesia, hanya 21 kontainer yang masuk setelah Indonesia melarang impor sampah plastik pada tanggal 22 Nopember 1992, dan hanya 1 kontainer setelah Indonesia 
meratifikasi Konvensi Basel yang mengatur tentang Pengawasan Perpindahan Lintas Batas Limbah Berbahaya dan Pembuangannya pada tanggal 12 Juli 1993.

Sebenarnya pemerintah sudah mendeteksi' adanya impor sampah atau limbah bahan berbahaya dan beracun pada tahun 1989, di mana ketika itu Menteri KLH mengirim surat imbauan kepada para gubernur agar menolak setiap impor sampah yang mengandung bahan berbahaya dan beracun yang masuk ke pelabuhan-pela-buhan di daerahnya. Namun massalah itu tidak ditindaklanjuti dengan pembuatan peraturan perundangundangan atau peratifikasian hasil Konvensi Basel pada waktu itu. Adanya kekosongan aturan hukum tersebut dimanfaatkan secara jeli oleh para pengusaha dan industriawan dari Belanda, Jerman, Amerika Serikat, Jepang, Singapura, dan Hongkong untuk mengekspor sampah atau limbah yang ada di negara mereka ke Indonesia. Para pengusaha dan kalangan industriawan Indonesia yang bergerak dalam industri daur ulang sampah membutuhkan sampah dari negara-negara industri tersebut sebagai bahan baku untuk industri daur ulang yang mereka kelola. Dengan adanya permintaan dan penawaran tersebut, maka kemudian lahir berbagai transaksi dagang sampah plastik dan limbah bahan berbahaya dan beracun.

Industri daur ulang sampah plastik sebenarnya tidak ada masalah sepanjang bahan bakunya tidak mengandung $B 3$, walaupun sampah plastik itu berasal dari hasil impor. Adalah sangat mengherankan, mengapa para pengusaha Indonesia mau mengimpor'sampah plastik mengandung B3 yang jelas-jelas tidak bisa didaur ulang. Motif negará-negara industri untuk mengimpor sampah plastik atau limbah lainnya, terutama sampah atau limbah yang mengandung $\mathrm{B} 3$ adalah karena alasan praktis dan ekonomis. Untuk mendaur ulang sampah dan atau membuang sampah yang mengandung $\mathrm{B} 3$ di negara-negara industri persyaratannya jelas sangat komprehensif dan biayanya juga sangat besar. Oleh kaena itu lebih praktis dan ekonomis jika diekspor ke negara lain. Dengan kata lain, kebijakan ekspor tersebut lebih menguntungkan daripada mengolah sendiri.

Bagi pengusaha dalam negeri impor sampah plastik yang tidak mengandung B3 dilatarbelakangi oleh motif bisnis untuk mendapatkan keuntungan yang sebesarbesarnya, karena harga plastik impor itu lebih murah daripada harga plastik yang dikumpulkan para pemulung. Namun tindakan mengimpor sampah plastik yang telah terkontaminasi B3 atau mengimpor limbah B3 itu sendiri sulit melacak motif yang melatarbelakanginya. Probabilitas yang paling mungkin adalah persekongkolan jahat dengan imbalan uang.

Dengan kasus sampah plastik impor ini terlihat bahwa hukum mempunyai peranan penting dalam kehidupan masyarakat. Hukum mengatur bagaimana kehidupan masyarakat seharusnya dilaksanakan. Tujuannya adalah untuk menciptakan kedamaian dalam pergaulan hidup bersama. Kedamaian akan tercipta apabila ada keter-tiban (keteraturan dalam interaksi sosial) dan adanya ketenteraman (kebebasan untuk mengekpresikan diri). Tanpa hukum tidak mungkin tercipta ketertiban dan ketenteraman dalam kehidupan masyarakat, termasuk ketertiban dan ketenteraman dalam ekspor impor sampah plastik dan bahan berbahaya dan beracun.

Di samping itu, pemerintah sebagai organ yang paling bertanggungjawab dalam penegakan hukum lingkungan memiliki standar ganda dalam penegakan hukum lingkungan. Pada satu sisi pemerintah begitu mendorong kalangan pengusaha dan industri agar peduli. dengan lingkungan hidup, khususnya dalam pengendalian pencemaran. Namun kalau ada kasus pencemaran yang 
dilakukan oleh pabrik-pabrik, ternyata sangat jarang yang diproses. Bahkan upaya-upaya yang dilakukan masyarakat untuk memperkarakan perusahaan pencemar ke pengadilan sering mengalami hambatan dari aparat penegak hukum sendiri.

Tujuan penegakan hukum bukan sekedar menghukum para pelanggar hukum, tapi yang lebih utama adalah agar anggota masyarakat yang lain tidak melanggar hukum pula. Aspek prevensi ini jauh lebih penting daripada penghukuman itu sendiri. Bagaimana mungkin menumbuhkan sikap takut atau jera di kalangan industriawan agar tidak mencemari lingkungan, jika para pelanggar (pencemar) ketentuan hukum lingkungan itu tidak diproses secara hukum.

Ketakutan pemerintah terhadap dampak negatif yang akan ditimbulkan jika pencemar diajukan ke pengadilan, yang akan mempengaruhi kehidupan ekonomi masyarakat, jelas terlalu berlebihan. Adanya proses hukum terhadap para pelaku pencemaran belum tentu mempengaruhi proses produksi perusahaan secara nasional. Kalaupun ada dampak terhadap proses produksi perusahaan, paling hanya berpengaruh terhadap perusahaan yang diadili tersebut. Ongkos sosial yang harus dikeluarkan warga masyarakat untuk mengatasi akibatakibat yang ditimbulkan oleh pecemaran tidak pernah dikalkulasikan sebagai kerugian dalam konteks kehidupan ekonomi. Barapa biaya kesehatan yang harus dikeluarkan oleh setiap rumah tangga yang menderita sakit akibat pencemaran, dan berapa penghasilan yang hilang karena orang kehilangan pekerjaan akibat pencemaran, penurunan kualitas air minum, biaya pembelian air bersih, penurunan kulitas tanah dan sebagainya.

Jika terjadi konflik kepentingan antara kepentingan industri dengan kepentingan masyarakat yang terkena dampak pencemaran, pemerintah secara umum lebih berpihak kepada kaum industriawan. Alasannya, jika perusahaan tersebut tidak berproduksi, maka negara akan rugi secara ekonomis, dan akan menimbulkan masalah ketenagakerjaan. Adanya ambivalensi .sikap pemerintah dalam penegakan hukum ini tergambar dari begitu banyaknya kasus-kasus pencemaran lingkungan yang telah diperiksa oleh aparat penyidik tidak dilimpahkan ke pengadilan. Kasus-kasus pencemaran yang telah diperiksa oleh aparat penyidik dan dipublikasikan melalui mass media banyak yang tidak jelas tindak lanjutnya.

Faktor lain yang menyebabkan terjadinya masalah sampah plastik impor ini adalah aparatur pelaksana hukum yang kurang profesional, terutama dalam sektor pengawasan di pelabuhan. Salah satu modus operandi masuknya sampah plastik impor ke Indonesia adalah melalui permalsuan dokumen-dokumen impor yang tidak terdeteksi oleh petugas Bea dan Cukai.

\section{E. Kebijakan Pemerintah Mengena! Sampah Impor \\ Pengolahan dan pembuangan} limbah B3 yang berisiko minimum bagi manusia dan lingkungan hidup merupakan tantangan penting bagi pemerintah dan juga bagi industri. Namun tidak semua negara dan industri mengambil kebijakan tersebut. Cara yang semakin banyak digunakan untuk mengatasi masalah ini adalah dengan mengangkut (mengimpor) limbah B3 ke negara lain: Cara ini adalah cara yang paling mudah dan ekonomis, karena jika mengolah sendiri biayanya cukup mahal. Oleh karena itu terjadi peningkatan permintaan investasi untuk pembuangan limbah. Indonesia merupakan salah satu tujuan dari pembuangan limbah $B 3$ ini.

Untuk mengantisipasi peningkatan permintaan untuk investasi pembuangan limbah B3 dari luar negeri tersebut, pada tahun 1989 Menteri Negara 
Kependudukan dan Lingkungan Hidup telah mengeluarkan surat yang berisi imbauan kepada seluruh gubernur di wilayah Indonesia untuk menolak tanah air Indonesia dijadikan tempat pembuangan limbah dari negara lain.

Walaupun sudah ada imbauan, namun kenyataannya, kasus sampah plastik impor disinyalir sudah terjadi sejak akhir.1991. Indikasi terjadinya manipulasi kasus pemasukan sampah plastik impor yang mengandung limbah $\mathrm{B} 3$ bérawal dari informasi para pemulung (scavengers atau plastic garbage collector). Limbah B3 tersebut bercampur dengan limbah plastik untuk didaur ulang. Salah satu contoh adalah ditemukan drum-drum yang bertuliskan Lechitine.

Kebijakan pemerintah dalam menghadapi masalah sampah plastik impor ini dapat dibedakan antara kebijakan pengaturan hukum (regulation policy) dan kebijakan penyelesaian kasus (case settlement policy).

\section{Kebijakan Pengaturan Hukum}

Ada tiga macam kebijakan pengaturan hukum yang dilakukan pemerintah untuk merespon kasus sampah plastik impor, yaitu pelarangan impor sampah plastik melalui Surat Keputusan Menteri Perdagangan No. 349/ $\mathrm{Kp} / \mathrm{Xl} / 1992$, peratifikasian Konvensi Basel yang mengatur tentang Pengawasan dan Perpindahan Lintas Batas Limbah Berbahaya dan Pembuangannya, dan Pembuatan Peraturan Pemerintah No. 19 Tahun 1994 tentang Pengolahan Limbah Bahan Berbahaya dan Beracun.

Dasar pelarangan impor sampah plastik menurut konsideran SK Menteri Perdangan No. 349/Kp/Xl/1992 adalah dalam rangka pencegahan pencemaran terhadap lingkungan dan kesehatan manusia yang diakibatkan oleh sampah plastik, khususnya yang berasal dari impor. Tindakan pemerintah melarang impor sampah plastik secara total, termasuk jenis sampah plastik yang dapat didaur ulang (positive list),. jelas memberikan keuntungan ganda bagi Indonesia. Pertama, berkurangnya - penumpukan sampah karena sampah plastik lokal dibeli oleh industri daur ulang, sehingga mengurangi beban pemerintah untuk menyediakan lahan pembuangan sampah. Kedua, penyediaan lapangan kerja bagi para pemulung dapat dilestarikan. Sayang sekali Surat Keputusan Menteri Perdagangan yang melarang impor sampah plastik tersebut. tidak disertai dengan sanksi hukum bila ketentuan tersebut dilanggar sehingga secara yuridis formal peraturan tersebut lemah.

Setelah melarang impor sampah plastik, Indonesia meratifikasi Basel Convention on the Control of Transboundary Movements of Hazardous Wasters and Their Disposal pada tanggal 12 Juli 1993. Konvensi Basel ini mengatur Pengawasan dan Perpindahan Lintas Batas Limbah Berbahaya dan Pembuang-annya.

Dasar pertimbangan meratifikasi Konvensi Basel tersebut adalah bahwa secara geografis wilayah Republik Indonesia terdiri dari. pulau-pulau dengan perairan terbuka, karena itu sangat potensial sebagai tempat pembuangan limbah berbahaya secara tidak sah dari luar negeri. Di samping itu, juga berdasarkan pertimbangan bahwa untuk memelihara kelestarian lingkungan serta mencegah agar wilayah Republik Indonesia tidak menjadi tempat pembuangan limbah berbahaya.

Untuk melengkapi kedua aturan tersebut, pada tanggal 30 April 1994 pemerintah memberlakukan PP No 19 Tahun 1994 tentang Pengolahan Limbah Bahan Berbahaya dan Beracun. Meskipun PP ini lebih banyak mengatur pengolahan limbah berbahaya dan bahan beracun yang dihasilkan dalam negeri, namun juga mengatur tentang pengawasan impor dan ekspor limbah B3. Ketentuan PP No. 19 Tahun 1994 Pasal 27 menyebutkan:

(1). Setiap orang atau badan usaha 
dilarang memasukkan limbah B3 dari luar negeri ke dalam Wilayah Negara Republik Indonesia.

(2). Pengangkutan limbah B3 dari luar negeri melalui Wilayah Negara Republik Indonesia, wajib dilakukan memberitahukan terlebih dahulu secara tertulis kepada Pemerintah Republik Indonesia.

(3). Pengiriman limbah B3 ke luar negeri dapat dilakukan setelah mendapat persetujuan tertulis dari pemerintah negara penerima dan mendapat izin tertulis dari Pemerintah Republik Indonesia.

(4). Ketentuan lebih lanjut mengenai tata cara pengiriman limbah B3 ke luar negeri ditetapkan Menteri Perdagangan setelah mendapat pertimbangan Badan Pengendali Dampak Ling-kungan.

Pelanggaran terhadap ketentuan dalam PP ini dapat dikenakan sanksi administratif berupa peringatan dan pencabutan ijin usaha. Pengangkutan limbah B3 yang menggunakan sarana transportasi yang tidak memenuhi ketentuan pengangkutan diancam dengan sanksi yang terdapat dalam peraturan perundang-undangan di bidang perhubungan.

Ketentuan-ketentuan lain yang dikeluarkan pemerintah dalam menghadapi masalah sampah plastik impor adalah sebagai berikut:

1. Surat Menteri Sekretaris Negara No. R-339/M.SESNEG/11/1992 yang berisi Petunjuk Presiden: Sebaiknya impor limbah plastik dan aki bekas dilarang. Surat dikeluarkan tanggal 30 Nopember 1992.

2. Surat Menteri Muda Perdagangan No. S-107/M/XII/ 1992 mengenai permintaan peninjauan kembali atas SK Menteri Perdagangan. Surat dikeluarkan tanggal 18 Desember 1992.

3. Surat Menteri Keuangan No. S-1571/
MK.00/1992 tentang Pemberian liin Pemasukan ke Daerah Pabean atas Party Limbah/Sampah Plastik yang dikapalkan dari negara asal sebelum atau pada tangal 25 November 1992. Surat dikeluarkan tanggal 30 Desember 1992.

4. Surat Direktorat Jenderal Pabean No. S-16/BC.3/1993 tentang Pelaksanaan SK Menteri - Keuangan. Surat dikeluarkan tanggal 5 Januari 1993.

5. Surat Dirjen Bea Cukai: RDG/Dirjen Bea Cukai/RDG No. 02/BC/1993 tentang Penghentian Pelaksanaan SK Menteri Keuangan. Surat dikeluarkan tanggal 3 Pebruari 1993.

6. Surat Keputusan Jaksa Agung: SKEP No. Kep-027/JA/2/1993 mengenai Pembentukan Tim Penanggulangan Impor Limbah. Surat dikeluarkan tanggal 12 Pebruari 1993.

7. Surat Dirjen Bea Cukai S-104/BC/1993 dan SE-06/BC/1993 tentang: (a) Importir dapat mengurus PIUD sampai tanggal 15 April 1993; (b) Kontainer yang tidak diambil sampai tanggal 12 April 1993 akan dilelang; (c) Lelang dilakukan dengan syarat: tidak mencemari lingkungan dan siap membeli sampah plastik pemulung dengan perbandingan 1:3.

Kedua surat tersebut dikeluarkan pada tanggal 15 Maret 1993 dan 16 Maret 1993.

8. Surat Wakil Sekretaris Kabinet No. 27/ WASESKAB/ 4/ 1993 berisi Petunjuk Presiden bahwa Limbah Impor agar dimusnahkan.

\section{Kebijakan Penyelesaian Kasus}

Untuk mencari pemecahan kasus sampah plastik impor ini, pemerintah telah membentuk Tim Penanggulangan Impor Limbah (TP4P) berdasarkan Surat Keputusan Jaksa Agung: SKEP No. Kep027/JA/2/1993. Tim TP4P terdiri dari Kejaksaan Agung (sebagai ketua), Bapedal, Ditjen Bea Cukai, Kepolisian, Departemen Perindustrian, Departemen 
Kesehatan dan instansi terkait lainnya (Departemen Perdagangan, Departemen Luar Negeri, dan Adpel) masing-masing sebagai anggota.

Dalam penanganan sampah plastik impor tersebut Tim telah melakukan pengecekan-pengecekan dokumen beserta barang, penelitian dan penyidikan terhadap importir serta mengambil kebijakan-kebijakan dalam menaati SK Meneteri Perdagangan untuk menolak masuknya limbah atau sampah plastik impor ke wilayah Republik Indonesia. Dalam pemeriksaan isi kontainer-kontainer sampah plastik impor yang tertumpuk di pelabuhan Tanjung Priok, Bapedal dan Ditjen Bea dan Cukai bersama-sama Kepolisian, Kejaksaan, Departemen Perindustrian, dan Departemen kesehatan telah melakukan pemeriksaan lapangan. Bapedal telah mengambil sampel limbah plastik tersebut untuk di tes laboratorium, kecuali untuk limbah plastik yang merupakan limbah rumah tangga dan limbah berlumpur, diperiksa secara visual. Untuk sampah plastik yang tertumpuk di pelabuhan Belawan Medan dan Tanjung Perak Surabaya, Bapedal telah bekerjasama dengan Biro Lingkungan Hidup Medan dan Surabaya dan meminta untuk melakukan pemeriksaan. Selain melakukan pemeriksaan lapangan, Ditjen Bea Cukai bersama Bapedal telah melakukan pengecekan-pengecekan dokumen/manifest.

Untuk mengetahui apakah sampah plastik impor didaur ulang dan diolah oleh importir sesuai dengan performan standar yang baik, Bapedal bersama kepolisian telah melakukan pengecekan ke lokasi industri di Tangerang yang merupakan salah satu industri penerima terbanyak sampah plastik impor. Berdasarkan hasil pengecekan lapangan, penelitian dan pengetesan (pengujian), pemeriksaan dokumen/manifest impor, dan peninjauan ke lokasi pabrik pengolah limbah, telah diperoleh hasil sebagaimana diuraikan berikut ini.
Pertama, jumlah sampah plastik impor sebanyak 261 kontainer, yang terdapat di pelabuhan Tanjung Priok Jakarta sebanyak 240 kontainer, di pelabuhan Tanjung Perak Surabaya sebanyak 15 kontainer dan di pelabuhan Belawan Medan sebanyak 6 kontainer. Sedangkan sampah plastik impor yang mengandung limbah B3 ada sebanyak 104 kontainer.

Dilihat dari waktu masuknya, ada 21 kontainer yang masuk setelah Indonesia melarang impor sampah plastik melalui SK Menteri Perdagangan, dan 1 kontainer setelah Indonesia meratifikasi Konvensi Basel.

Kedua, proses pengiriman telah dimanipulasi, baik oleh eksportirnya maupun oleh importirnya dengan management yang baik. Dokumen-dokumen impor/manifest dimanipulasi sedemikian rupa. Sejumlah kontainer limbah plastik impor yang dalam dokumen dinyatakan berisi PVC scrap ternyata juga berisikan limbah yang lain yang berbeda dari pernyataan dalam dokumen/manifest. Ketiga, sampah plastik impor tersebut hanya beberapa persen saja yang didaur ulang dan tidak memenuhi performan standar yang baik serta tidak memenuhi upaya pengelolaan lingkungan yang baik. Berdasarkan hasil temuan Tim tersebut, penyelesaian masalah sampah plastik impor ini ditempuh melalui dua cara (kebijakan), yaitu penyelesaian secara hukum, dan penyelesaian secara nonhukum. Penentuan cara penyelesaian, apakah secara hukum atau nonhukum tergantung kepada kedudukan kasusnya. Bagi sampah plastik impor yang BL-nya masuk setelah keluar SK Menteri Perdagangan Nomor $349 / \mathrm{Kp} / \mathrm{XI} / 1992$ tentang Larangan Impor Sampah Plastik, akan diselesaikan secara hukum.

Sedangkan sampah plastik impor yang BL-nya sebelum keluar SK Menteri Perdagangan tersebut diselesaikan secara nonhukum, yaitu: (a) Yang masuk negatif list (yang mengandung limbah B3 dan tidak 
dapat didaur ulang) yaitu sebanyak 104 kontainer direncanakan akan direekspor ke negara asalnya yaitu dengan telah diberitahukannya hal ini kepada kedutaan besar masing-masing negara tersebut, dan (b) Yang masuk positif list (tidak mengandung limbah B3 dan dapat didaur ulang) sebanyak 125 kontainer sudah ada izin untuk diambil oleh importir. Dari jumlah 125 kontainer itu, 56 kontainer telah diambil oleh importir, sedangkan 69 kontainer belum diambil. Kontainer sampah plastik yang PIUD-nya setelah tanggal 15 April 1993 akan dilelang.

Untuk merealisasikan rencana reekspor tersebut pemerintah Indonesia, dalam hal ini Departemen Luar Negeri telah menyampaikan rencana reekspor sampah plastik yang masuk negatif list kepada negara-negara pengekspor (Belanda, Jerman, Singapura, Jepang, Amerika dan Hongkong). Hal itu telah disampaikan oleh Dirjen HELN kepada kedutaan besar negara-negara tersebut di atas dengan mengeluarkan pernyataan agar :(a) Penyelesaian Limbah B3 di pelabuhan Indonesia ini secepat mungkin;(b) Kejadian ini jangan sampai berulang lagi di masa datang; (c) mengimbau agar masalah ini jangan hanya menjadi masalah legal saja, dan (d) kasus Limbah B3 di pelabuhan Indonesia ini sangat peka dan bisa mengarah pada situasi memburuk secara politik.

Rencana Pemerintah Indonesia dalam menangani sampah plastik impor yang masuk daftar negatif list tersebut adalah mereekspor ke negara asalnya. Pemerintah Belanda telah menanggapi rencana pemerintah Indonesia tersebut yaitu dengan mengirim tim penyidik VROM Belanda ke Indonesia. Selain Belanda, rencana reekspor sampah plastik tersebut telah ditanggapi pula oleh pemerintah Jepang, yaitu dengan mengirim kuesioner untuk dijawab oleh pemerintah Indonesia, dalam hal ini Bapedal.

Pemerintah Indonesia menginginkan biaya reekspor sampah plastik impor yang mengandung B3 tersebut ditanggung oleh pemerintah negaranegara pengekspor, yaitu pemerintah Belanda, Jepang, Amerika Serikat, Jerman, Singapura dan pemerintah Hongkong, meski langkah ini akan mengalami banyak kesulitan (tidak bisa dipaksakan) karena dasar hukumnya tidak kuat. Apalagi perusahaan-perusahaan pengekspor dan perusahaan-perusahaan pengimpor diduga banyak yang fiktif. Pada akhirnya akan tergantung pada kesepakatan antara pemerintah Indonesia dengan pemerintah negara-negara pengekspor di meja perundingan.

Upaya hukum yang dilakukan pemerintah yang akan menuntut para importir yang mengimpor sampah plastik sesudah adanya Surat Keputusan Menteri Perdagangan No. 349/Kp/XI/1992 dengan penyelundupan adalah tepat, karena SK Menteri Perdagangan tersebut menentukan kualifikasi illegal atau tidaknya perdagangan sampah plastik yang diimpor ke Indonesia. Dengan kata lain, mengimpor sampah plastik setelah adanya SK Menteri Perdagangan merupakan tindakan illegal. Sedangkan upaya pemerintah tidak menuntut para importir yang mengimpor sampah plastik sebelum SK tersebut, jelas kurang tepat, karena para importir tersebut dimungkinkan pula dituntut secara hukum, termasuk dengan tuntutan delik penyelundupan.

Dari pemeriksaan kasus di lapangan diketahui bahwa modus operandi impor sampah plastik itu dilakukan dengan cara memalsukan dokumen impor dan penyebutan jumlah dan jenis barang yang tidak sesuai dengan keadaan barang yang sebenarnya. Pemalsuan dokumen impor dan pemutarbalikan fakta barang termasuk kualifikasi tindak pidana penyelundupan.

Dengan demikian para importir yang mengimpor sampah plastik sebelum adanya SK Menteri Perdagangan yang menggunakan modus operandi pemalsuan dokumen impor dan pemutarbalikan fakta barang tentu saja dapat dituntut dengan 
delik penyelundupan.

Pemerintah tidak menggunakań UU No. 4/1982, khususnya ketentuan pasal 22, untuk menjaring para importir sampah plastik, karena proses pembuktian terjadinya pencemaran sangat sulit dan harus melalui pengujian laboratorium.

Meskipun ada indikasi pembuangan sampah plastik yang mengandung $\mathrm{B} 3 \mathrm{di}$ tempat pembuangan akhir sampah.(TPA) dan timbulnya penyakit gatal-gatal yang diderita para pemulung yang menyortir sampah tersebut dengan tangan telanjang, namun indikasi tersebut tidak cukup memadai untuk dijadikan alat bukti. Timbulnya penyakit gatal-gatal belum tentu mempunyai korelasi langsung dengan sampah plastik yang mengandung B3. Di samping itu, perusahaan yang membuang sampah plastik yang mengandung $B 3$ tersebut tidak bisa diidentifikasi.

Penyelesaian secara 'nonhukum melalui upaya diplomatik untuk merekspor sampah plastik yang mengandung B3 ke negara asalnya adalah tepat, karena tidak membutuhkan prosedur yang panjang. Namun jika upaya ini gagal, maka harus diselesaikan melalui arbitrase seperti yang dikehendaki oleh Konvensi Basel.

\section{F. Saran-saran}

Dalam rangka menangtisipasi kemungkinan-kemungkinan buruk di masa depan diperlukan peraturan perundangundangan yang bersifat antisipatif, sehingga persoalan-persoalan yang akan terjadi dapat disiapkan sarana penanggulangannya sejak awal sehingga dampaknya terhadap kehidupan masyarakat dan lingkungan hidup dapat dieliminasi. Peran serta masyarakat dalam pengelolaan lingkungan hidup juga perlu ditingkatkan, karena masyarakat bukan hanya dapat memberikan informasi untuk pengungkapan kasus-kasus lingkungan, tapi juga dapat membantu pemasyarakatan. dan penaatan hukum lingkungan dan mendemokratisasikan proses pengambilan keputusan yang mengatur kehidupan mereka.

Disamping itu penegakan hukum lingkungan hendaknya dilaksanakan secara konsisten, bukan hanya supaya para pencemar menjadi jera dan terhindarnya lingkungan dari risiko kerusakan dan pencemaran, tapi juga supaya anggota masyarakat yang lain tidak melanggar hukum (prevensi umum).

\section{DAFTAR PUSATAKA}

Abdurrahman. Pengantar Hukum Lingkungan Indonesia. Bandung: Alumni, 1986.

Amsyari, F. Prinsip-Prinsip Masalah Pencemaran Lingkung-an. Jakarta: Ghalia Indonesia, 1976.

Buntoro, C.I. Beberapa Aspek Pencemaran Plastik Dan Pengaruhnya Terhadap Pertumbuhan Tanaman Jagung. Yogyakarta: Zeamays Fakultas Biologi UGM, 1986.

Danusàputra; Munadjad. Hukum Lingkungan Buku l: Umum. Bandung: Binacipta, 1980.

Hardjasoemantri, Koesnadi. Hukum Lingkungan. cet. kedelapan. Yogyakarta: Gadjah Mada University Press, 1991. Hukum Tata Lingkungan. Yogyakarta: Gadjah Mada University Press, 1988. - Aspek Hukum Peran Serta Masyarakat Dalam Pengelolaan Lingkungan Hidup. Yogyakarta: Gadjah Mada University Press, 1986.

Komisi Dunia Untuk Lingkungan dan Pembangunan. Hari Depan Kita Bersama. Jakarta: PT. Gramedia, 1988.

Lotulung, Paulus Effendi, Penegakan Hukum Lingkungan Oleh Hukum Perdata. Bandung: Citra Aditya Bakti, 1993.

Mahida, U.N. Pecemaran Air. cet. pertama. Jakarta: Radjawali, 1984.

Salim, Emil. Pembangunan Berwawasan Lingkungan. Jakarta: LP3ES, 1989. Lingkungan Hidup dan Pembangunan. Jakarta: Mutiara, 1982.

Silalahi, Daud. Hukum Lingkungan. Bandung: Alumni, 1992.

Soemarwoto, Otto. Ekologi Lingkungan Hidup dan Pembangunan. cet. keempat, Jakarta: Djambatan, 1989.

Suparni, Niniek. Pelestarian, Pengelolaan, Dan Penegakan Hukum Lingkungan. Jakarta: Sinar Grafika, 1992. 